This article was downloaded by: [Viaene, Lieselotte]

On: 6 October 2010

Access details: Access Details: [subscription number 927470798]

Publisher Routledge

Informa Ltd Registered in England and Wales Registered Number: 1072954 Registered office: Mortimer House, 3741 Mortimer Street, London W1T 3JH, UK

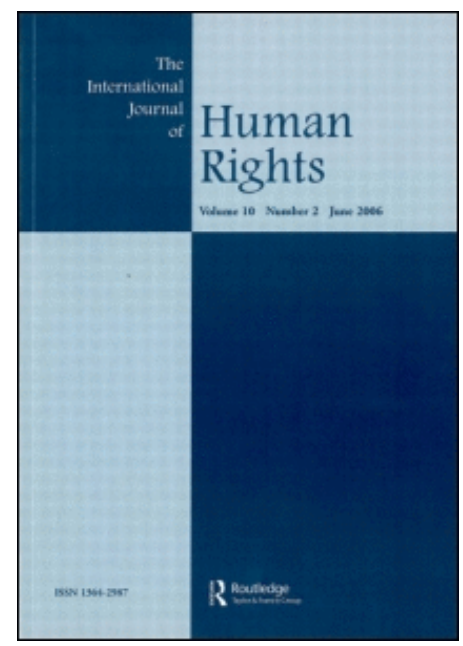

\title{
The International Journal of Human Rights
}

Publication details, including instructions for authors and subscription information:

http://www.informaworld.com/smpp/title content=t713635869

Dealing with the legacy of gross human rights violations in Guatemala: grasping the mismatch between macro level policies and micro level processes

Lieselotte Viaene ${ }^{\mathrm{a}}$

${ }^{a}$ Human Rights Centre, Ghent University, Belgium

First published on: 30 September 2010

To cite this Article Viaene, Lieselotte(2010) 'Dealing with the legacy of gross human rights violations in Guatemala: grasping the mismatch between macro level policies and micro level processes', The International Journal of Human Rights,, First published on: 30 September 2010 (iFirst)

To link to this Article: DOI: 10.1080/13642987.2010.511995

URL: http://dx.doi.org/10.1080/13642987.2010.511995

\section{PLEASE SCROLL DOWN FOR ARTICLE}

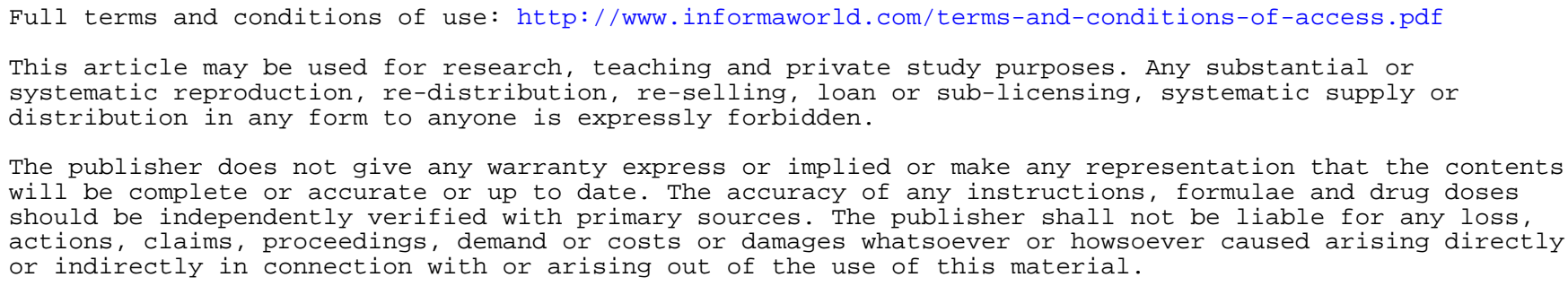




\title{
Dealing with the legacy of gross human rights violations in Guatemala: grasping the mismatch between macro level policies and micro level processes
}

\author{
Lieselotte Viaene* \\ Human Rights Centre, Ghent University, Belgium
}

\begin{abstract}
This article addresses the important nexus between macro level responses and micro level processes when dealing with the aftermath of gross human rights violations. It focuses on the case of Guatemala and the issue of financial compensation for people affected by the internal armed conflict. One of the key mechanisms of the horror of the counterinsurgency war was the forced mass involvement of the civilian population through the imposition of the Civil Defence Patrols in rural indigenous communities. This raises the thorny question of who is victim in a micro reality of blurred lines between victims and perpetrators. Several socio-political parameters ensured that two distinct compensation programmes were created: one aimed at compensating the ex-civil patrollers; and a National Reparations Programme for the victims. Ethnographic accounts from Maya Q'eqchi' victims and ex-civil patrollers reveal that these two state initiatives expose frustration and incomprehensiveness among the beneficiaries towards both programmes and reveal a mismatch between macro initiatives and micro reality, which undermines the fragile process of rebuilding community trust.
\end{abstract}

Keywords: transitional justice; Guatemala; reparation; compensation; victim/perpetrator dichotomy; Civil Defence Patrols; bottom-up and top-down analysis; ethnographic field research

\section{Introduction}

Countries emerging from authoritarian rule and periods of gross human rights violations face considerable challenges. During the post-conflict process, questions about the restoration of the rule of law, institutional reforms and security sector reforms are given high priority on the national and international peace building agenda. Another concern is that of how to deal with the legacy of the gross human rights violations. Crucial here is the booming field of transitional justice which covers the different strategies and interventions that states and international actors employ to deal with the legacy of mass atrocities. Currently, there is a preference for a mix of judicial and non-judicial mechanisms which includes criminal prosecution and trials, truth commissions, vetting and reparation programmes. ${ }^{1}$ They are designed to achieve the fields' driven goals which are justice, reconciliation, truth recovery, guarantees of non-repetition and reparation. Indeed, since its emergence some 15 years ago, the trend in the field is towards a new transnational normative system. ${ }^{2}$ Yet transitional justice is also undergoing a process of natural maturating from a young but quickly expanding field of inquiry. One of the outcomes of this process is

*Email: Lieselotte.Viaene@UGent.be 
the growing awareness among scholars and practitioners that the current transitional justice field is highly abstract, general, legalistic and top-down. ${ }^{3}$ In a significant pendulum motion, academic thinking has now swung toward bottom-up, interdisciplinary, empirical and concrete approaches. Currently, several interrelated trends that coincide in their attempts to re-orient the field can be seen. First, there is a trend in academic thinking and in the international community to move away from the 'one size-fits-all' approach to transitional justice ${ }^{4}$ because, 'given the extraordinary range of national experiences and cultures, how could anyone imagine there to be a universally relevant formula for transitional justice?'. 5 Secondly, a consensus has emerged in favour of changing lenses and broadening the scope by looking closer at what is happening at the grassroots level. Concepts that are gaining currency in recent debates include 'transitional justice from below', 'local approach', 'bottom-up', 'macro-micro', and 'local ownership'. Indeed, there is a need for a 'transitional justice from below' which aims to explore ways of how 'from above' transitional justice institutions and structures 'can broaden ownership and encourage the participation of those who have been most directly affected by the conflict'. ${ }^{6}$ Indeed, there is an emerging recognition that the expectations and the priorities of the affected people should be taken into account at all stages of transitional justice interventions - conceptualisation, design, implementation and management. ${ }^{7}$ The underlying premise is that those mechanisms should serve the interests of the survivors in whose name the state and international actors intervene. It is therefore crucial to understand what affected people seek from peace and transitional justice interventions. Further, there is a tendency of using traditional and informal justice systems and revisiting traditional and local culture as a means of coming to terms with mass atrocities. ${ }^{8}$ Indeed, cultural challenges also constitute part of this critical reflection process. Nevertheless, there is little information in the field on how survivors perceive the driven goals of transitional justice and its mechanisms in different local and cultural contexts. Moreover, it remains rare to find empirical studies that base policy recommendations on consultations of future beneficiaries or that examine the difficulties and issues that arise while implementing peace and transitional justice driven processes.

Additionally, based on a case study of post-conflict Guatemala and the issue of financial compensation for people affected by its internal armed conflict, this paper asserts that due attention should be paid to the interconnection between macro level driven initiatives and micro level processes when dealing with gross human rights violations. The case of Guatemala's internal armed conflict is another example of what is labelled in post-conflict literature an 'intimate' crime. This concept refers to situations of armed conflicts, such as Mozambique, BosniaHerzegovina, Sierra Leone, Peru and Rwanda, marked by a highly localised dimension, mass civilian participation as well as involvement of civilian agents in the atrocities. ${ }^{9}$ As Schirmer states in relation to the situation in Guatemala, 'nowhere else in Latin America, an army managed to mobilize and divide an indigenous population against itself to such an extent even to the point of forcing victims to become accomplices and kill one another'. ${ }^{10}$ Indeed, one of the key 'mechanisms of horror" ${ }^{\text {'1 }}$ of the Guatemalan counter-insurgency war was the forced mass involvement of the civilian population through the imposition of the Civil Defence Patrols (Patrullas de Autodefensa Civil - PAC) in rural indigenous communities. ${ }^{12}$ In fact, these PACs became the personification of the militarisation of rural indigenous areas. In such contexts of intimate crime, the qualification of who is victim is a thorny question because the violence creates more 'grey zones' ${ }^{13}$ than the clear victim-perpetrator dichotomy. Indeed, at the local level of indigenous communities the lines between victims and perpetrators were blurred which has had a severe impact on local social recovery processes.

Against this background, the paper looks at two recent but distinct state programmes of financial compensation for people affected by the conflict and their impact at the local level. 
As Theidon argues, 'reconciliation is forged and lived locally, and state policies can either facilitate or hinder these processes'. ${ }^{14}$ In Guatemala, there is on the one hand the programme of compensation for ex-civil defence patrollers, and the National Reparations Programme that compensates victims of the conflict on the other. Both state programmes emerged in a complex political but very polarised context and address the demands of what at the macro level is seen as two separate and homogenous groups: ex-civil patrollers or perpetrators and victims. However, at the micro level, this victim versus perpetrator dichotomy is much more blurred than it is diametrical. In fact, ethnographic accounts from Maya Q'eqchi' victims and ex-PACs reveal that these two state initiatives undermine the fragile local social recovery processes among survivors. This paper seeks to grasp this mismatch between post-conflict macro level policies and micro level processes, discusses the complexities at the different levels and attempts to interconnect both levels. By focusing on the 'social and political life' ${ }^{15}$ of the concept of compensation in the specific context of Guatemala, it also attempts to contribute to the knowledge gap in transitional justice literature on localised approaches. The broader research question underlying this paper is about the role of Maya Q'eqchi' culture in post-conflict processes at the local level. To address this research question 21 months of ethnographic research was conducted between July 2006 and March 2010 in the Alta Verapaz department, which is situated in the north central part of the country. It is one of the most affected regions of the conflict and the large majority of the population is indigenous Maya Q'eqchi'. While the current trend in the transitional justice field is to use population-based surveys on attitudes on peace and social reconstruction that ensure a broad scope, it is argued that this approach fails to explore the deeper local cultural logics in which needs, perceptions and attitudes are embedded. For instance, Shaw considers ethnographic research to be the most appropriate approach when studying post-conflict processes at the local level because it seeks to understand processes, events and ideas on the people's own terms and thus is a powerful tool for challenging received wisdom and for understanding events and processes on the ground. ${ }^{16}$ Further, ethnographic micro level research is, according to Pouligny, Chesterman and Schnabel, 'very helpful in understanding the capacity of victims and perpetrators to reconstruct new forms of social ties'. ${ }^{17}$ The research was conducted in three regions of Cobán municipality which is part of the Alta Verapaz department: Nimlahak'ok, Nimlasachal and Salacium. To address the complex local and cultural reality multiple data collection techniques, or methodological triangulation, have been used. The research included semi-structured focus group discussions with internally displaced people, war widows, elderly and ex-PACs; linguistic workshops; formal and informal interviews with community leaders, spiritual guides, and local and foreign people with experiences of the conflict and social reconstruction; participant observation during community meetings and commemorative ceremonies were conducted. For most survivors it was their first opportunity to share their opinions regarding coexistence, justice, reconciliation, reparation and truth recovery, especially ex-PACs who regularly expressed their gratitude that someone finally was listening to them. ${ }^{18}$ Further, several key stakeholders of national human rights groups and indigenous victim organisations and interlocutors of civil society were interviewed.

This article begins with a macro level analysis of how Guatemalan society is dealing with the legacy of gross human rights violations, then shifts to a micro level description of the intimate crime first and ends by linking both levels. The first section begins with a brief sketch of the armed conflict and of the PAC system in Guatemala. The second section outlines several interrelated socio-political variables of the broader macro level context that are crucial in understanding the origin and different dynamics in which the 
two state programmes are embedded. In the third section, this paper examines the complexities of the conflict and social recovery processes at the micro level. The next section proceeds to examine the perceptions of both ex-civil patrollers and victims regarding the two state programmes. This exposes frustration and incomprehensiveness among the beneficiaries towards both programmes and reveals a mismatch between macro initiatives and micro reality, which undermines the fragile process of rebuilding community trust.

\section{Guatemala: dealing with its past of intimate crime}

Guatemala has suffered one of the bloodiest and longest internal armed conflicts of the Latin American continent, a conflict between the state's army and left-wing guerrillas who wanted to change fundamentally the exclusionary social, economic and political reality of the majority of the Guatemalans. This resulted in a low-intensity civil war lasting 36 years which finally ended on 26 December 1996 with the signing of comprehensive peace agreements between the Guatemalan Government and the Guatemalan National Revolutionary Unity (URNG). At the beginning of the 1980s the conflict intensified under the administrations of Generals Romeo Lucas García (1978-1982) and Efraín Ríos Montt (March 1982-August 1983) who launched bloody military campaigns and scorched earth strategies as part of the counter insurgency war. Over 200,000 people were killed or disappeared during this period. According to the UN sponsored Commission on Historical Clarification $(\mathrm{CEH})$, most of the victims were indigenous civilians and acts of genocide against Mayans were carried out in at least four areas of the country. ${ }^{19}$ The country suffered 626 massacres, over 400 villages were totally destroyed, 1.5 million people were internally displaced and 150,000 fled to Mexico. Of the killings, massacres, forced disappearances and torture, the $\mathrm{CEH}$ found the army responsible for 93 per cent. Further, the PACs were responsible for 18 per cent of human rights violations. Their main violations were: capture or execution of (so-called) guerrilleros, torture and sexual violations.

The imposition of the PAC system in the early 1980s was a central element of the military counter-insurgency strategy of total control of the rural indigenous areas. The PACs were created in 1981 by General Lucas García and became part of the National Security and Development Plan of the military government of Efraín Rios Montt in 1982. ${ }^{20}$ They were men between 15 and 60 years who functioned as the ears and eyes of the army in their villages. They were also forced to take over military tasks like sweeping areas for guerrillas and attacking so-called subversive villages. Their total number remains unclear, but at the peak of the war in the mid-1980s they numbered between 1,000,000 and 1,300,000 men, declining over the years to 400,000 in 1995. According to Remijnse, a central aspect of the PAC was 'their diversity between and within municipalities, and consequently their varied and often unpredictable impact on local society... . Civil patrols were not static entities, but different in background, the type of functions they performed, and their level military activity'. ${ }^{21}$ The army has since 1982 continually been asserting the voluntary nature of the PACs. However, early studies showed that throughout the 1980s, the PACs were forced to patrol on penalty of severe punishment or death. ${ }^{22}$ Several ethnographic studies on the destructive impact of the conflict have detailed how PACs were victims of the army and at the same time were perpetrators towards their own neighbours. ${ }^{23}$ These studies show how this system in some areas created space for chiefs of patrollers to abuse their authority whilst ruling with impunity, to terrorise their village and region and serve their own interests. In 1986, under the civil government of Vinicio Cerezo, the civil patrols were renamed Voluntary Committees of Civil Defence (CVDCs), to emphasise the voluntary nature of their work. ${ }^{24}$ 
During the peace process, which took almost a decade, the demilitarisation of the state and civil society and the concern of impunity of those responsible for human rights violations stood high on the international agenda. In fact, the UN, together with other international actors, played a crucial mediating role in facilitating agreements between the government and the URNG. ${ }^{25}$ The mix of agreements opened up an opportunity for a significant transformation of Guatemalan society and resulted in long-term commitment to change the country into a democratic, inclusive and pluri-cultural state. ${ }^{26}$ They covered commitments on socio-economic reforms and the agrarian situation, rights of indigenous peoples, human rights, public security reforms and resettlement of refugees and displaced persons. The agreements also demobilised the guerrilla forces and members of different state and parastatal security forces.

During these peace negotiations the future of the PACs was also at issue. Human rights defenders argued that their demobilisation and disarmament would put an end to the human rights abuses. It was, however, not clear what would happen to the structures of the system thereafter and there was no political room for a formal demobilisation, demilitarisation and reintegration (DDR) programme or any other kind of benefits or compensation for the PACs. ${ }^{27}$ Several reasons for their exclusion in the peace agreements can be traced. First, the URNG opposed equal treatment of the PACs with their own forces for which a DDR programme was elaborated with support of the international community. ${ }^{28}$ A second reason is that neither the government nor the army proposed to deal with the PACs during the negotiations. ${ }^{29}$ Another reason for the exclusion lies in the fact that the army from 1995 onwards, tried to convert PACs into 'committees of peace and development' maintaining the existing structure for development and public safety in the rural areas. This raised the concern among human rights defenders that the army was trying to maintain unofficial influence and control over important actors and funds in the communities. Therefore, according to Popkin, the international community did not want international help for the development of the rural areas to be transferred to these kind of committees. ${ }^{30}$ A final reason is that the negotiations on the agreements on human rights and the establishment of the CEH has been difficult; therefore as Hauge and Thoresen maintain, putting a reintegration and compensation programme for the PAC on the agenda would have been a delicate issue and put extra negative pressure on the negotiations. ${ }^{31}$

The Agreement on the Strengthening of Civilian Power and on the Role of the Armed Forces in a Democratic Society of September 1996 obliged the Guatemalan Government to demobilise and disarm its own forces. According to this Agreement, the PACs had to be demobilised within 30 days and they should cease any relationship with the army and not be converted in any way that might reconstitute that relation. At that time the PACs had already formally been dissolved by the Ramiro de León Carpio government through a presidential decree in $1994 .{ }^{32}$ However, reports of the UN verification mission of human rights (MINUGUA) demonstrated that there were threats and attacks against patrollers wanting to leave. ${ }^{33}$ Further, the reports mention that there were still military commissioners $^{34}$ and patrollers controlling rural villages and cases of abuse and violations of the right to live, integrity and security. It was difficult to give a clear answer to whether PACs existed or had been dissolved between 1994 and 1996 as this varied depending on region, department and municipality and their relationship with the army. ${ }^{35}$ Further, ethnographic accounts of PAC in the Western Highlands attributes this continuation to fear for the army, a way out of the violence; a means of self-defence and a growth of a sense of sovereignty within the communities. ${ }^{36}$ By December 1996, in total 270,906 PAC-members were demobilised under the supervision of MINUGUA. ${ }^{37}$ However, some ex-PAC leaders and ex-commissioners maintained their power and control over the communities. ${ }^{38}$ 


\section{Compensation for people affected by the armed conflict}

De Greiff points out that one of the huge challenges that any reparation and DDR programme faces is to determine the future beneficiaries, namely how to select the rights which the violation of will lead to reparation measures and how to avoid the exclusion or over-inclusiveness of ex-combatants. ${ }^{39}$ The specific Guatemalan transitional justice context makes this qualification process even more complex. Before moving to the description of the origin and content of the two state programmes of compensation, it is crucial first to sketch briefly several parameters that characterise the social-political climate.

First, it is important to note that, according to the Guatemalan Human Rights defender Helen Mack:

... it is clear that a clear reference to reconciliation in the peace agreements was deliberately omitted, despite the fact that such a process is indispensable for overcoming the adverse conditions at the negotiations. . . because the concept of 'reconciliation' asks for major social, political and institutional transformations, for which the Guatemalan society is not prepared, especially those groups who have the power. ${ }^{40}$

She further states that there is a lack of a shared conceptualisation of reconciliation at the national level and a real reconciliation process has never been stimulated. In fact, the lack of a common national peace agenda and concept on reconciliation has its repercussions on the state's efforts to deal with the legacy of the conflict: minimal progress in the accomplishment of the peace agreements has been made due to the absence of political will.

Secondly, since their creation in the early 1980s, the PACs have been subject to two decades of commotion and heated national debates. Importantly however, there has never been an open national discussion about the definition of victimhood or an attempt to nuance the homogeneity of the PACs as perpetrators. In fact, their complexity and diversity has been omitted during the peace process by the negotiation parties and civil society. Actually, the discussion about the PACs during the negotiations in the early 1990s was centred on one question: was the participation in the civil patrols voluntary or not? ${ }^{41}$ Early studies ${ }^{42}$ had already indicated their involuntary nature and this has later been confirmed by the two truth commissions, the CEH and the project for Recovery of Historical Memory (REMHI) of the Catholic Church. In fact, the final report of REMHI described the PACs as one of the 'mechanisms of horror' ${ }^{43}$ Edgar Gutierrez, ex director of REMHI and ex minister of foreign affairs during the Portillo government, attributes the lack of a discussion about the heterogeneity of the PACs to a one-side reading of the conflict at the macro level as there has been little reflection on military, psychological, cultural, sociological and economical dimensions of the conflict. ${ }^{44} \mathrm{He}$ in fact states that for civil organisations simplifying the conflict and using the victim-perpetrator dichotomy has been comfortable and politically correct. Human rights groups generally portrayed the PACs as a homogenous group of perpetrators who operated at the local level of the indigenous communities. Another crucial fact in understanding the polemic on the ex-PAC is the hard reality that accountability remains susceptible because the impunity of the armed forces for past atrocities persists after 25 years. Only in three cases of the 669 documented massacres by the CEH have those materially responsible been successfully prosecuted by the Guatemalan judicial system. ${ }^{45}$ Therefore, the fight against the institutionalised impunity is the key concern and focus of human rights organisations. In their discourse, those organisations maintain the polarity between ex-PACs as perpetrators on the one hand and victims on the other. According to Jelin this polarisation is inherent to the interpretive framework of human rights violations because "the polarity is between human rights violators on one side 
and victims on the other'. ${ }^{46}$ In fact, Bores states that in human rights discourses 'victims and perpetrators are usually referred to as two completely separate and homogenous sets of people'. ${ }^{47}$ However, she further argues that 'differences between the two groups are perhaps not as clear-cut as human rights scholars and activist...tend to portray them and that highlights that the homogeneity that is assumed about the individuals within each group is similarly overstated' ${ }^{48}$ Nevertheless, if against the background of this macro level context of total impunity, national human rights organisations were to start making a plea in favour of a more nuanced reading of the conflict, this would undermine their legitimacy as human rights defenders in their quest for justice. Yet this strategic macro level position of human rights organisations clashes with the complex and blurred micro reality of the affected rural communities as will be shown in the next section. In fact, sticking to a strict victim-perpetrator dichotomy in such a context is what Goveir and Verwoerd describe as 'logically simplistic, ethically unfair, psychologically misleading and prudentially undermining, 49

A final important contextual element is that peace building and transitional justice efforts are very top-down driven in Guatemala and do not take into account local and cultural resources. Several human rights professionals working for years in the countryside, have in interviews raised the fact that all governmental and (inter)national non-governmental organisation (NGO) policies and programmes are designed in the capital based on a 'far away vision'. ${ }^{50}$ In this 'capital-bubble' it is the vision of the ladino ${ }^{51}$ that still dominates and most of the time is not familiar with the reality of the transitional complexity of rural indigenous areas.

Against this socio-political backdrop and the political commitments of the peace agreements two distinct state programmes of compensation for people affected by the conflict were created.

\section{Compensation programme for ex-PACs ${ }^{52}$}

The exclusion of the PACs in the peace agreements generated an accumulation of bitterness among some ex-PACs which created a boomerang effect with a strong claim for compensation from the state. ${ }^{53}$ The first demand for compensation was publically made in 1997 in the Petén department. This was the first wave of unrest among former civil patrollers. It was Alfonso Portillo, the presidential candidate for the right wing Guatemalan Republican Front (FRG), who in 1999 again placed the issue of compensation for ex-PACs at the forefront. ${ }^{54}$ He promised to pay ex-PACs for their services to defend the country and private property against communism. ${ }^{55}$ Ex-PACs used this electoral promise as their main argument in their future compensation claims. Demands for financial compensation resurfaced in June 2002 when ex-PACs in the Petén blocked the airport of Flores and other strategic places. President Portillo travelled to the Petén and gave a speech in which he promised that the government would satisfy their demands. After negotiations an agreement on compensation was reached and the government announced a new special tax to finance this. Consequently, ex-PACs started to remobilise in different regions and municipalities throughout the country. Interestingly, this occurred mainly in regions with low intensity experience or even lack of the internal conflict and thus low ex-PACs presence, whereas those ex-PACs who qualified as perpetrators of atrocities did not remobilise nor demand compensation. ${ }^{56}$

A heated discussion emerged in which human rights organisations accused the FRG government of exploiting the situation in view of the coming elections. ${ }^{57}$ Under this pressure the government changed its tax proposal and acquired international loans. 
Originally, the demand was Q20,000 (\$2,750) per person, but finally the total amount was Q5,214 (\$717) which would be paid in three instalments. Between November 2002 and June 2003 ex-PACs and widows of ex-PACs could register at the administrative centre of each department. The first payment of Q1,747.20 (\$240) was made during the Portillo government in 2003 and benefited a total of 188,959 people of which 176,123 were ex-PAC and 12,836 widows. ${ }^{58}$ There was a huge protest from human rights organisations, the UNRG and international embassies against this payment. ${ }^{59}$ As the national human rights organisation CALDH formulated it in the press: 'intimidation, torture, disappearances and massacres cannot be considered a dignified and remunerative job' ${ }^{60}$ Civil society was also concerned about the impunity which PAC members enjoyed for human rights violations and about the lack of agreement on reparations for victims.

Therefore, several human rights organisations brought an action against this measure before the Constitutional Court which in 2005 judged it to be unconstitutional. The main argument was that no labour contract existed between PACs and the state because their service was considered voluntary. The new government of Berger changed the modality of the compensation in 2005 into a programme of 'Planting Trees' and provided Q445 million (\$61 million). ${ }^{61}$ Seventy million trees were planted by ex-PACs who would receive the promised two other payments as compensation for this reforestation work. In total 544,620 ex-PACs registered for the programme of whom, currently, 15 per cent have not received the third payment. ${ }^{62}$ However, not all PACs on the list received all three payments, due to bureaucratic problems and also because some of them refused to work for the government to receive their compensation.

\section{National Reparations Programme (PNR)}

The creation of a reparations programme was a long and complex process that faced numerous obstacles and was defined by political struggle. ${ }^{63}$ During the peace negotiations, national victim organisations strongly demanded reparation measures for the victims of the conflict. Reparation demands became a state commitment with the General Agreement on Human Rights ${ }^{64}$ of 1994 forming part of the peace agreements. This states that reparation and/or assistance to victims of human rights violations is a humanitarian obligation. Furthermore, the $\mathrm{CEH}$ recommended immediate installation of a reparation programme over ten years which includes restoration of material possessions, compensation, psychosocial rehabilitation and reparation as well as restoration of individual dignity and satisfaction. The CEH defined that the beneficiaries are victims (or their relatives) namely 'those persons who have personally suffered human rights violations and acts of violence connected with the internal armed confrontation'. ${ }^{65}$

Interestingly, the $\mathrm{CEH}$ also recommended collective measures, depending on the type of violation, to foster reconciliation between victims and perpetrators without stigmatising either $^{66}$ :

Therefore, collective reparatory measures for survivors of collective human rights violations and acts of violence, and their relatives, should be carried out within a framework of territorially based projects to promote reconciliation, so that in addition to addressing reparation, their other actions and benefits also favour the entire population, without distinction between victims and perpetrators.

The political conflict on the payment of PACs in 1999 paradoxically made political room for serious negotiations between the Portillo government and civil society for the creation 
of a reparations programme. Yet the Portillo's government finally approved a National Reparation Programme (PNR) by an Executive Decree in $2003 .^{67}$ The PNR had a comprehensive reparation design with five measures: material restitution, economic reparations, psychosocial reparation and rehabilitation, honouring civilian victims and cultural reparations. Due to lack of political will, differences among civil society organisations and the PNR's weak legal basis, its implementation was postponed until 2005 when a new Executive Degree ${ }^{68}$ was promulgated containing regulations for a restructured PNR. The Manual of Qualification of the Beneficiaries of the PNR that defines who is the beneficiary of the PNR clearly states that all ex-PAC that appear in the register of the programme for the payment of ex-PACs, even if they have not received any instalment, are excluded from any reparation measure of the PNR. ${ }^{69}$ Although the original measures remained, individual financial compensation was prioritised for several reasons. The organisation of the implementation of financial compensation is the 'easiest' one of the five and victim organisations also strongly demanded it. The beneficiaries are survivors of torture or sexual assault and relatives of victims of illegal executions, massacres or disappearances. The compensation is Q24,000 $(\$ 3,300)$ for a deceased relative and Q10,000 $(\$ 1,370)$ Q20,000 $(\$ 2,750)$ for sexual assault and/or torture. Since its start in 2005, the PNR has compensated 26,041 beneficiaries. ${ }^{70}$ At the end of 2009, the PNR started with the implementation of the measure of material restitution through pilot projects of housing. In total, 888 stone houses of six by six metres have been built. ${ }^{71}$

Before looking at how these two state initiatives are perceived by their beneficiaries and their impact on the local reconstruction processes, the ways Maya Q'eqchi' are dealing with this legacy of intimate violence will be explored. As there exist no monolithic experience of the conflict in Guatemala, first follows a brief contextualisation of the conflict in the Alta Verapaz department.

\section{Complexity of transitional communities at the micro level}

The CEH report shows that, after El Quiché and Huehuetenango, Alta Verapaz was the third worst-affected department by human rights violations and the Q'eqchi' ethnic group was the second worst-affected. ${ }^{72}$ The semi-feudal system on the fincas or big plantation farms, characterised by a lack of freedom, miserly low salaries, high work pressure, abuse and absence of schooling, is indicated as the root cause of the conflict in the department. ${ }^{73}$ Due to the scorched-earth tactics between 1981 and 1983, at least 40 per cent of the Q'eqchi' were displaced from their communities and 20,000 were forced to live as hidden refugees in the mountains for months or even years. ${ }^{74}$ They struggled to survive in the mountains in extreme conditions and were constantly forced to move place, resulting in death from hunger, disease and susto (fright or spirit loss). The most severely hit municipalities were Cobán, Chisec and San Cristobal. In addition to the scorched earth strategy in the regions of guerrilla presence, the army also imposed the formation of the PACs in the rural areas that were under military control. The total amount of the PACs during the conflict is unclear; however during the demobilisation in 1996, the department had the second-highest number of patrollers in the country $(72,699) .{ }^{75}$ Alta Verapaz's PACs were responsible for seven per cent of human rights violations, whereas in El Quiché, 46,995 PACs were responsible for 59 per cent of the violations. ${ }^{76}$ The reason for this high difference in responsibility is unclear. Probably it is related to lower reporting and less active functioning of the CEH office in Cobán. ${ }^{77}$

With the amnesty offered by Ríos Montt's government in 1982 and the military policy of promoting a large-scale return of internally displaced people, many Q'eqchi', decimated 
by prosecution and hunger, decided to return from the mountains. ${ }^{78}$ Thousands of displaced Q'eqchi' were taken in by the army and moved to military camps or 'Poles of Development' in the region, where they usually received ideological 're-education' ${ }^{79}$ The men were obliged to patrol the camps and had to sweep the area for guerrilla camps and search and convince groups who were still hiding in the mountains to return. Indeed, two groups of PACs can be distinguished in the region: the men who were under military control from the beginning of the scorched-earth campaigns and the internally displaced men who first survived months or years hiding in the mountains and who had to patrol in the military camps and later in their communities.

Toward the end of the 1980s, the military camps closed and the internally displaced people had to relocate and reintegrate into the region. This difficult and complex process generally happened in three ways: the return to the old villages, the incorporation into other villages and the creation of new villages. ${ }^{80}$ During the initial phases of relocation, displaced people faced humiliations, accusations and threats from PACs and those who had stayed in their villages. The army had created a climate of fear and hostility, as part of its psychological war, causing deep distrust of those 'from the mountains' (aj rub'el pim) who were seen as guerrilleros. The search for land in the region caused frictions among survivors and divided groups and families. Returnees from Mexico could count on support from the international community and the state to buy land, whereas the internally displaced were forgotten. The army also forced some displaced people to occupy the land and territory of people who had fled to Mexico, which created conflicts with the returnees who reclaimed their land. ${ }^{81}$ Until their formal demobilisation in 1996, PACs remained in the villages of the region.

Social reconstruction in the Q'eqchi' region proceeded slowly, due to no aid from the state and little aid from national or international organisations. Places and regions such as Rabinal in Baja Verapaz, the Ixil Triangle and the returnees from Mexico in the Ixcán, both part of the Quiché department, over the years received strong national and international attention. Even today, compared to those regions, a strong presence of international agencies, NGOs or the state in projects designed to support Q'eqchi' in Alta Verapaz is lacking. It was mainly the Catholic Church that played a role in local social reconstruction in some affected areas through the social interventions of the Pastoral Social in Cobán and later the work of the REMHI-Alta Verapaz office. Almost 25 years after the massacres, the survivors still face structural inequities. Alta Verapaz counts the highest number of land conflicts of the country. ${ }^{82}$ Further, the people must deal with poverty caused by the contrast between the high cost of living and very low incomes, discrimination and abandonment by the state, and finally divisionism provoked by the conflict. ${ }^{83}$

The CEH clearly stated that the magnitude of the violence and the imposition of the PACs had seriously undermined trust within many communities and caused a rupture in the Mayan social fabric and indigenous authority system, disrupting the social norms and elements of the cultural identity. ${ }^{84}$ The process of "picking up the pieces ${ }^{\prime 85}$ is very difficult in regions that have suffered intimate crime and where people who have committed atrocities in their own community are living together with their victims. The necessity of interdependent social and economic survival procured an inevitable co-existence of divided people. In the regions of Nimlahak'ok, Salacium and Nimlasachal, people have engaged with the legacy of the mass atrocities. The ways Q'eqchi' victims and ex-PACs have reconstructed new social ties varies between communities depending on how they had been affected, the possibility of obtaining land during the relocation process and the persistent political power of ex-chiefs of PACs. Nonetheless, it is clear, as will be illustrated, that they have not waited for the formal justice system to be rebuilt and/or interventions of 
national and international actors implemented to start the process of 're-imagining peace ${ }^{86}$ or reshaping social norms, practices and relationships and of finding a new modus vivendi.

The expression nimla rahilal that Q'eqchi' victims and ex-PACs use when referring to the period of the conflict reveals their cultural understanding of the conflict. Nimla is large; rahilal means suffering and pain (physical, emotional and spiritual). Nimla rahilal always refers to the sort of pain that is the result of a 'final' loss: the loss of a family member or the loss of a harvest or home due to natural disaster. A final loss implies pain that cannot be relieved; it is an irreparable loss. Indeed, the pain and suffering caused by the nimla rahilal will never leave the heart of the survivors as one displaced man put it: 'It is like a thorn in our souls, it is like having a knife in our stomachs.'

Furthermore, the conflict not only violated their human rights and caused human suffering; it also violated and transgressed social and spiritual norms established by the communities, leading to the breakdown of their tuqtuukilal (tranquillity, harmony, peace). The expression xоо'e'xтих, which frequently appears during interviews with survivors, means 'they desecrated the cosmos and us as humans'. This reflects the desecration of the natural, social and spiritual world, because of the destruction of the holy maize fields and the sacred mountains (Tzuultaq'a). ${ }^{87}$

Despite the abandonment by NGOs and the state, people in the Nimlahak'ok region made remarkable efforts in the mid-1990s to confront the local history of political violence. In November 1995, a huge white cross was erected on the highest hill, with two marble plaques bearing the names of 916 victims. This was the result of an extensive, wellcoordinated process that started in 1994 involving 28 communities in an area of $600 \mathrm{~km}^{2}$. At its origin lay dreams of a number of elders about a large white cross emerging from a mountain, which according to Flores was interpreted as 'a supernatural sign from their disappeared relatives who died during the violence and who had not been buried in accordance with traditional practices' ${ }^{88}$ The names on the marble plaques belong to victims of the massacres, but also to people who disappeared or died from malnutrition, disease or susto (fright or spirit loss) in the mountains. Also included are names of victims who were PACs.

Remarkably, although fear still ruled, some PAC members of the neighbouring village Salacium helped with the construction of the cross. Salacium, at that time a three-hour walk across a sloping landscape, had a very different experience of the war. This village was totally controlled by the military base of Playa Grande and formed the limit of the scorched-earth campaigns. So the men were forced to patrol the village and the region. The commissioners and chiefs of PACs of the village provoked terror and fear. ${ }^{89}$ In Salacium, similar to other regions under military control, many people converted to evangelical churches during the conflict to save their lives as the Catholics were accused of being 'communists' and 'guerrilleros'. This is the main reason why the people of Salacium did not participate in the construction of the cross. The people from Nimlaha'kok received several threats from commissioners and chiefs of PACs of Salacium that they would destroy the cross. However, despite this, some of their PACs members gave the names of their dead relatives and helped with its construction.

Each year, since 1995, on 3 November and on the Saturday before Easter, a Mayan ceremony and community celebration take place near the cross to commemorate the loss of loved ones. An important leader stated that the cross is not only for the community of Sahak'ok but for the entire region and that:

... it is a road to bring us to a dialogue and would lead to a revival among us. So that we would not be longer rejected, not only those who suffered the violence [in the mountains], but also those who did not suffer. ${ }^{90}$ 
Some years ago, a non-asphalted road was constructed connecting Cobán with Playa Grande and passes the two villages. The cross is visible from far away when coming from both directions. Now ten years later, these evangelical ex-PACs from Salacium are acknowledging the importance of the cross. As one ex-PAC says:

For me it is not a lie [what happened during the conflict]; that cross has been built because the violence has occurred. So, it is a sign because it happened, it is a sign for the compañeros. How many were burned during that violence? That's why they made that sign where the names of those who died appear; it is true all the names are there (group interview, May 2008).

Other ex-PACs from Salacium say that 'the cross is a sign of the armed conflict, of the problems and everything that happened during those times', 'it is a sign and a testimony that cannot wipe out the violence which happened among us' and 'it reminds us that what happened is true'. The cross is an important locally and culturally driven experience of memorialisation, recovery and dissemination of historical memory.

Another important sign of the slowly proceeding social recovery process in the region is the fact that currently, in the Nimlaha'kok region, the two main local authorities administrating the region are an ex-PAC who never hid in the mountains and an ex-guerrilla leader. For seven years this ex-PAC has been the president of an important regional council and in 2008 an ex-guerrilla leader became the mayor of the region. Both were asked by the people to take up this important responsibility. ${ }^{91}$ Fostering unity in the region is what binds these two leaders. However, here a too-romanticised and harmonious reading of such local social reconstruction processes must be avoided. Complex social, economical and power realities should not be overseen in understanding the ways of social recovery.

As one local leader from Sahak'ok explains:

There are people who did understand; there are people who want to life united, who want to be in community [together]. But there are also people who don't want to be in the community, there is divisionism and there are confrontations. There is divisionism because of the different religions in the different regions. There is no goodness; there is no tranquillity (personal interview, May 2008).

An ex-PAC compares the impact of the conflict on communal life with a destroyed beehive:

It is difficult now; it is difficult for us to come together as one, because it has all fallen apart, yes. You could say that it is like an ants' nest that was destroyed or a beehive, they all go their own way - you cannot bring them together anymore (group interview, July 2007).

For example, Salacium, with its mix of victims on both sides and strong presence of ex-PACs, is still a conflictive village and region. Before the war, economic power belonged to several ladino families who owned almost all of the land. The conflict has not changed this unequal power relation between ladinos and indigenous people, as the majority of indigenous families in Salacium still rent parcels from them to provide their basic needs. The presence of eight different evangelical churches in the centre of the village does not really foster unity.

In Xalab'e, a remote community in the Nimlasachal region, another large cross was erected in 1999 to commemorate 468 victims from 24 communities. This cross, surrounded by mountains, stands in the middle of the region where the massacres took place. Also here, ex-PACs from the neighbouring villages helped with the construction of the cross and names of PAC victims appear. One leader of this community who lost family members 
when hiding says that at first there were many accusations from ex-PACs towards them, those 'from the mountains'. Yet, over the years their behaviour has changed and the reproaches have stopped. As he says: 'we are seeing each other as equals...now there exists again some usilal [goodness]'. This leader even proposed that it would be good to engage a mutual understanding of the different experiences with the conflict.

Besides these overt and visible local experiences on social recovery and reconciliation ethnographic accounts reveal that beneath that surface there is substantial activity that at first glance is invisible. In fact, Maya Q'eqchi' survivors have managed to mobilise local and cultural practices on justice and reconciliation to face the legacy of the atrocities and to find a new modus vivendi. ${ }^{92}$ At the local level of Q'eqchi' communities, impunity, as defined by international law, is not the end of accountability, nor truth recovery or reparation. Here, the internal logic of the cosmos through an invisible force creates a space in which local perpetrators can reintegrate into communal life and through which victims' pain and suffering are acknowledged.

In the next session the perceptions of both Q'eqchi' groups regarding the programme of compensation for the ex-PACs and the PNR will be discussed.

\section{The mismatches between post-conflict macro level policies and micro level processes}

As mentioned, state interventions can foster or hinder processes of local social recovery. Ethnographic accounts from Q'eqchi' victims and ex-PACs reveal that both state programmes seriously crosscut and undermine the fragile social recovery process, stirring up emotions amongst them and even leading to an incomprehensiveness toward the state as such.

\section{Frustrations towards the PAC programme and the PNR}

There is a growing awareness among victims that ex-PACs were forced to participate in the conflict and also suffered. However, the victims are deeply frustrated and disillusioned that ex-PACs have already received compensation. Most PNR beneficiaries have to wait for financial compensation, sometimes for over four years. For victims it is difficult to understand how the government can 'reward' those who are co-responsible for their suffering and pain. As one victim says: 'they are not dignified to receive this aid'. The fact that ex-PACs managed to be heard through manifestations by several presidential candidates and governments, offended victims. Victims, who participated in the CEH or the REMHI investigation, stated that they had heard for years that help was coming, but the promises remained unfulfilled. It affronted victims that during the political debate on PACs compensation, the PAC stated that they had suffered. Victims acknowledge the suffering, but it was certainly not equal. According to the victims the suffering of the PACs was different because, as they stated during interviews, 'they never lost their houses', 'they could "come home" after patrolling', 'they did not starve from hunger', 'they did not live as animals in the mountains' and 'if they had lost someone, they could bury their loved ones properly'. Further, many displaced people recall that ex-PACs had financial benefits during the war as they regularly cleared out the houses that they had left behind. So, although the passage of time makes victims aware of the heterogeneity of ex-PACs and the forced character of their violent acts, the victims are internalising and using strategically the macro level victim-perpetrator dichotomy in discussions about PAC compensation.

Among ex-PACs, several perceptions exist in relation to their compensation. Most ex-PACs think that they deserved the payment because they were forced to patrol, 
during which they could not work and could not provide for their families. The army also prohibited them from going to their fields in the mountains, because they could be seen and accused of being one of 'those from the mountains'. The men suffered physically as they had to patrol in the cold, rain and mud. Several elders complained that they are still suffering. As one ex-PAC says:

For our children it served, for our wives it served, but for us men, no, there is nothing. The only thing we had was hunger, having to put up with thirst in the little post, during the whole night, every day (Group interview, May 2008).

There are many complaints about the bureaucratic problems of the PAC programme. Several elders could not fulfil the bureaucratic requirements because of a lack of the required documents. Others have only received one or two instalments. There are also ex-PACs who disagreed with the 'Planting Tree' programme, because they found it incorrect that they had to work again to receive the rest of the instalments, as they had patrolled already during the conflict.

The strict bureaucratic requirements also affected many war widows whose husbands patrolled during the conflict. The representative of the ex-PACs in the region of Salacium explains that some of the war widows applied for the PAC programme, but could not present the necessary documents such as the PAC identification card of their husband or the marriage act, so did not receive the PAC compensation. ${ }^{93}$ In fact, as he further explains, because these widows now appear on the PAC lists, they have lost the right to be beneficiaries of the PNR, even if they are internally displaced and thus victims.

Further, ex-PACs feel deceived by the government, because much higher levels of compensation were promised. They were not informed that the reforestation programme included the maintenance of the planted trees. The travel costs and food during working days is not reimbursed. Many ex-PACs, certainly in Salacium, expressed their discontent about the continuing demonisation of them in the national press and by human rights organisations.

Also the PNR with its prioritisation on individual financial compensation fails to provide real satisfaction for both the remedied victims and those whose cases are still pending. ${ }^{94}$ It creates a sentiment of guilt not only toward deceased relatives, but also toward others who have suffered, but who, for bureaucratic reasons have not obtained compensation. As an internally displaced man says:

Paying for violence. We do not like it either, it is like I said, they are only paying for the dead: it is like for my mother, they are going to pay me for her. I will eat my mother, I will chew my mother. What I would like is for all those who suffered from the violence to be helped (Personal interview, August 2007).

Evidence from the interviews suggests widespread endorsement of complementary collective reparation measures. A beneficiary of the PNR says:

But I don't like the fact that they are helping those who have died. For us it would be, that everyone who suffered from the violence, that they should receive help. I don't like the fact that they are not being helped (Group interview, September 2007).

Further, victims asked for restitution or compensation from the government for destroyed material possessions, such as houses, livestock, cornfields, beans, clothes, millstones and traditional instruments. One major request of victims and ex-PACs is that they be granted title to land. Because of the finca system, most Q'eqchi' do not possess any 
land, not even a small parcel. As previously said, heated land conflicts continue to this day in Guatemala, with the highest concentration in Alta Verapaz.

Remarkably, during the interviews, no compensated ex-PAC complained about the smaller amount received in comparison with the beneficiaries of the PNR, but several ex-PACs expressed their concern that not all widows receive the financial compensation from the PNR. A local authority, once an ex-PAC leader, states:

I hear that not all the señoras are receiving compensation. There should be a law that executes that, because they also are poor. Or they should give them a house so that they can live well (group interview, July 2007).

However, with the older ex-PACs much frustration and disappointment exist for never having received any help from the government, whereas returnees from Mexico have received houses and development projects in the 1990s and currently displaced people receive houses from the PNR. An old ex-PAC says that the government is acting as a father that only loves one of his sons and not both:

We are old and we patrolled, but where is the goodness [usila], where is the welfare that the president talked about? No one loves us; they love the one but not the other. It is like a father that loves one son but not the other. That is what they are doing to us and we don't have money. On what are we going to live when we don't have money, and we are already elders, so we cannot manage to work anymore (group interview, April 2008).

This image reflects a more profound frustration among ex-PACs, namely that during the conflict they did not have the opportunity to choose their role as PAC/perpetrator. Now, when finally social and financial benefits are arriving to the communities affected by the conflict, again they are modelled in a role that they cannot choose.

\section{'We are all sons of the government'}

As the PAC programme succeeded prior to the creation of the PNR, several internally displaced people, who later had patrolled in the military camps, registered themselves on the PAC lists in the course of 2002 and 2003. In some communities there was, at the time of the registration, an internal critical reflection about this compensation which made displaced men who had patrolled in the military camps not register, because they identified themselves more as victims than as PAC. In fact, this critical reflection occurred mainly in communities in which the Catholic Church by the Pastoral Social or the REMHIAlta Verapaz office had worked. In other regions this critical refection did not take place and displaced people registered on the PAC lists because of economic needs. Indeed, the extremely poor conditions of the indigenous people were an important motive to apply to the PAC programme even though they were victims. In fact, 41.2 per cent of the population of Alta Verapaz live in extreme poverty, the highest percentage in the country, and Alta Verapaz (84.1 per cent), together with El Quiché (84.6 per cent), houses the greatest number of people living in total poverty. ${ }^{95}$ At the time of the PAC registration there were already national negotiations going on about a national reparation programme, but this was information that did not reach the communities. Indeed, the fact that those appearing on the PAC lists would lose future rights of being a beneficiary of such a reparation programme was unknown. The harsh micro reality of the blurred line between victim and PAC/perpetrator is not taken into account when taking the political decision to exclude all PACs from the PNR. Therefore, men who had lost family members through 
the army's actions, but were still forced to patrol, applied to the PAC programme, but therefore also lost the right to be a beneficiary of the PNR.

Even more, the recent implementation of the measure of material restitution is confronted at community level with this blurred line and the heterogeneity among ex-PACs. In Alta Verapaz 19 communities have benefitted from the housing project of the PNR and in several communities families have been excluded from the project because they appear in the PAC register. ${ }^{96}$ For example in one community of the Nimlahak' ok region, only six of the 25 families who applied for this reparation measure will receive a house due to this exclusion. However, those 25 families all lost their houses during the scorched-earth campaigns of the army and family members hid for several years in the mountains. Those men define themselves as victims because they have lost everything and define the PAC as those who helped the army to massacre them, but for purely economic reasons they applied under the PAC programme. ${ }^{97}$

In fact, at the micro level the PACs is no longer an active mechanism of physical horror that is involved with human rights violations towards its own people. Now it is an active mechanism of psychological horror towards individuals and their families. The two distinct compensation programmes confront not only the internally displaced men who patrolled in the camps with this perverse reality; they also confront others whose conflict experience left other blurred traces.

A striking account is that of Juan, from Salacium whose mother, father, sister and brother were killed by soldiers and whose uncle, father-in-law and brother-in-law died in a massacre carried out by guerrillas. He was forced to participate as a patroller, so was a victim of both sides and is ex-PAC. For Juan the most important thing is that aid reaches every survivor, because 'we are all children of the government':

Hopefully the government, yes, I wish that they help us with the suffering that we had to live with, that they help us with this pain, because I don't want, and I don't like, that only some are helped. And I, as I'm not a son of the government, because all of us are sons of the government, not only me, not only those who suffered violence in the mountains, we are all children of the government (group interview, May 2008).

As several key stakeholders of civil society have stated in interviews, the old ideological divisions remain playing an essential role at the level of national politics and civil society. Therefore, the question of whether ex-PACs may also be viewed as victims and the reality of forced perpetrator are taboo. This has serious consequences. The state's unequal treatment not only generates disappointment among victims and ex-PACs but also frictions in the communities. In fact the specific design and management of both programmes re-victimises victims and ex-PACs. Here, it is important to note that the recommendation of the $\mathrm{CEH}$ to promote local reconciliation and overcome stigmatisation of victims and perpetrators has never been assumed, nor by the succeeding governments, nor the international or national human rights organisations. In turn, they adopted the definition of victims of the $\mathrm{CEH}$ including returnees and internally displaced people, but excluded PACs who were victims of human rights violations.

Further, although many ex-PACs are also traumatised and face inevitable psychological challenges, it appears that major national NGOs giving psychosocial attention in affected communities are excluding them from their sessions, both because they perceive ex-PACs as perpetrators and because the NGOs see it as the army's responsibility to give mental health support to their (ex)forces. Over the years, as interlocutors have pointed out, a more nuanced vision on ex-PACs seems to have been adapted by some human rights defenders. 
For example, the current representative of the National Victim Movement, acknowledges difficulties that survivors are facing with the PNR regarding 'victim/ex-PAC' and favours focusing on the violation of human rights as departure criteria and not 'who is victim (returnee and internally displaced person)' and 'who is PAC', certainly in the case of widows. ${ }^{98}$ This opinion is shared by a state representative directly responsible for the management of the PNR; however he states that he holds a minority position in the whole discussion. ${ }^{99}$

\section{Conclusions}

This bottom-up analysis of the way Guatemala is dealing with its past of gross human rights violations shows the importance of understanding and interconnecting the socio-political and cultural complexities on both macro and micro levels. It reveals how macro level initiatives can cross-cut local social recovery processes when there is a mismatch between those two levels. In fact, in the absence of a more localised approach, macro level policies will not succeed and may even undermine those local recovery processes. Further, the above assessment attempted to demonstrate that defining who the victims are is a thorny question in societies dealing with the legacy of 'intimate' crime, marked by a highly localised dimension and mass civil participation of atrocities that created blurred lines between victims and perpetrators. Similarly, post-conflict Peru has been confronted with the difficult question of who deserves to be victim and who does not. During the design of the Integral Plan of Reparations (PIR), a debate broke loose on the concept of 'clear hands' as elaborated under international human rights law which dictates that people who ask for redress should have clear hands. ${ }^{100}$ In the Peruvian case this refers to the exclusion of members of illegally armed groups, such as the Shining Path, and their families who suffered state abuse from the PIR. Yet, this debate has led to strong tensions between legal considerations and political realities. The law codifying the PIR has adopted the Clear Hands Doctrine through which the PIR's implementation is faced with inquiring at the local level who deserves reparations. Laplante, however, wonders what type of instability and new conflict this will introduce in local communities who have achieved a delicate local peace and reconciliation environment. ${ }^{101}$

Yet, this transitional-justice-from-below analysis of Guatemala also raises several pertinent questions.

If the state and civil society had taken into account the recommendation of the CEH to provide collective reparation measures to foster reconciliation among victims and perpetrators at the local level, could this have led to a more nuanced perception of the homogeneity of PACs? Could this have stimulated the creation of a typology of PACs in which those who abused their power could be distinct from those who acted under coercion? What probably would have occurred would be the real confrontation between on the one hand the 'topdown' institutions and organisations and the local blurred accounts, such as presented here, on the other. This confrontation with the harsh local reality could have nurtured an elaboration of subcategories of PACs among the designers and financial donors of both state programmes. This would have been very helpful in defining the beneficiaries of a reparation programme and in defining perpetrators that should be prosecuted for human rights violations. Yet, this assumption implies that survivors have sufficient political agency and power to influence enough of those top-down institutions and interventions to change their agenda and interests by taking into account the real needs and priorities. It remains an open question whether survivors, such as the Maya Q'eqchi', have built sufficient citizenship capacity to play at the forefront of those macro level policies. Currently, both victims and ex-PACs are more likely the playthings of the different political parties 
to gain votes in the elections than having their aspirations taken seriously. Not only the exPACs are an interesting fish pool for political parties, victims are too. 'Both groups are politically manipulated. ${ }^{, 02}$ Due to its weak legal status, the PNR is very sensitive to political interest. Several victim organisations have already openly complained about the politicisation of the PNR and its departmental offices since the government of Colom took power in 2008. ${ }^{103}$

Another significant and interrelated question is whether this typology at the macro level would have avoided new political polarisation and the resurgent divisionism at the local level? This is highly probable. It would have significantly empowered the political agency of both victims and ex-PACs and fostered a shared identity of people affected by the conflict. The presented ethnographic accounts reveal that in the complex reality of transitional communities people are not passive, but actively confront the violent past and its legacy. Reflecting on Guatemala's micro reality, the conception of Mamdani as 'survivor', instead of victim versus ex-PAC, is very useful as it refers to 'all those who continue to be blessed with life in the aftermath of civil war', i.e. people should move beyond the dichotomy of victim-perpetrator as a way of searching for new forms of justice and coexistence. ${ }^{104}$

This bottom-up account shows further that the analysis and interpretation of the survivors' own perceptions and ideas are therefore a necessary precondition and fundamental step in the design and creation of whatever kind of benefits programme. In post-conflict societies dealing with a legacy of intimate crime, this is an important step in fostering local reconciliation and mutual understanding of grey zones among survivors and helping to overcome stigmatisation of victims and perpetrators.

The following words of an elder ex-PAC demonstrate how transitional justice efforts should be designed:

Well, [if] the government would take us [victims and ex-PAC] into account, would love us, then there would be peace. [Indeed] that broken bowl would be reconstructed, I would say, because we would be in a community. But now, it seems that we are still in [the situation] of that bowl being broken, because we have not yet figured out where we are in this, yes (group interview, May 2007).

\section{Acknowledgments}

The author wishes to thank Eva Brems, Bernard Dumoulin, Alfonso Huet, Nadine Janssens and Manuel Paau for their warmth during the fieldwork periods and together with Edgar Gutierrez, Rachel Sieder, Juan Santiago Quim and An Vranckx for their incisive and helpful comments on earlier versions of this analysis. Special thanks is also due to Abelino Cao Botzoc and all of the other Q'eqchi' for their participation and encouragement during the research. Funding for this research was provided by the Research Foudation-Flanders (FWO).

\section{Notes}

1. The Rule of Law and Transitional Justice in Conflict and Post-Conflict Societies: Report of the Secretary-General, UN SCOR, UN doc. S/2004/616 (2004).

2. Contributions to the normative development of transitional justice in international law are for example the UN declaration of basic principles and guidelines on the right to a remedy and reparation for victims of gross human rights violations. There is also a growing body of case-law from both the Inter-American Court of Human Rights and the European Court of Human Rights, which have addressed allegations of human rights violations in a transitional justice context. A clear example of this development is the 'right to truth' as an emerging rule of international law. Further there is also a process of judicial institutionalisation with the 
establishment of the International Criminal Tribunal for the Former Yugoslavia (ICTY), the International Criminal Tribunal for Rwanda (ICTR) and the International Criminal Court (ICC).

3. Béatrice Pouligny, Simon Chesterman and Albrecht Schnabel, 'Introduction: Picking up the Pieces', in After Mass Crime. Rebuilding States and Communities, ed. Béatrice Pouligny, Simon Chesterman and Albrecht Schnabel (Tokyo: United Nations University Press, 2007), 1-16; Kieran McEvoy and Lorna McGregor, 'Transitional Justice From Below: An Agenda for Research, Policy and Praxis', in Transitional Justice from Below. Grassroots Activism and the Struggle for Change, ed. Kieran McEvoy and Lorna McGregor (Oxford: Hart Publishing, 2008), 15-45.

4. The Rule of Law and Transitional Justice in Conflict and Post-Conflict Societies: Report of the Secretary-General.

5. Diane Orentlicher, 'Settling Accounts Revisited: Reconciling Global Norms with Local Agency', International Journal of Transitional Justice 1 (2007): 18.

6. McEvoy and McGregor, 'Transitional Justice From Below', 5 (emphasis in original).

7. See: The Rule of Law and Transitional Justice in Conflict and Post-Conflict Societies: Report of the Secretary-General; Orentlicher, 'Settling Accounts Revisited'; Patricia Lundy, and Mark McGovern, 'The Role of Community in Participatory Transitional Justice', in Transitional Justice from Below. Grassroots Activism and the Struggle for Change, ed. Kieran McEvoy and Lorna McGregor (Oxford: Hart Publishing, 2008), 99-120.

8. See: Lieselotte Viaene and Eva Brems, 'Transitional Justice and Cultural Context: Learning from the Universality Debate', Netherlands Quarterly of Human Rights 27, no. 2 (2010): 199-224.

9. Béatrice Pouligny, 'Building Peace in Situations of Post-Mass Crimes', International Peacekeeping (2002): 201-20; Kimberly Theidon, 'Justice in Transition: The Micropolitics of Reconciliation in Postwar Peru', Journal of Conflict Resolution, no. 50 (2006): 433-57; Béatrice Pouligny, Simon Chesterman and Albrecht Schnabel, eds, After Mass Crime. Rebuilding States and Communities (Tokyo: United Nations University Press, 2007).

10. Jennifer Schirmer, The Guatemalan Military Project: A Violence Called Democracy (Philadelphia: University of Pennsylvania Press, 1998), 81.

11. Inter-Diocesanal Project for the Recovery of Historical Memory (REMHI), Guatemala: Nunca Más. Informe del Proyecto Interdiocesano de Recuperación de la Memoria Histórica, (Guatemala: ODHAG, 1998). REMHI was the second truth commission organised by the Catholic Church.

12. In Guatemala the large majority of the population belongs to indigenous groups such as the Maya, The Xinka and Garifuna. The majority are Mayan which are constituted by 22 Maya ethnic groups of which the Quiché, Mam, Kaqchiquel and Q'eqchi' are the biggest groups.

13. Primo Levi, Survival in Auschwitz (New York: Touchstone, 1995).

14. Theidon, 'Justice in Transition', 246.

15. A phrase which I borrow from Kimberly Theidon. Kimberly Theidon, 'Editorial Note', International Journal of Transitional Justice 3 (2009): 296.

16. Rosalind Shaw, 'Memory Frictions: Localizing the Truth and Reconciliation Commission in Sierra Leone', International Journal of Transitional Justice 1, no. 1 (2007): 183-207.

17. Pouligny, Chesterman and Schnabel, 'Introduction: Picking up the Pieces', 3.

18. All interviews were in Q'eqchi', conducted with the help of an interpreter and recorded. The survivors' quotes appearing in this paper are extracts from those interviews. These (translated) vignettes attempt to represent an appropriate balance between reflecting the nuance of Q'eqchi' oral tradition (the authenticity of the expression of the ideas) and English written language.

19. Comisión para la Esclarecimiento Histórico CEH), Guatemala: Memoria del Silencio. Tz'inil Na 'Tab'Al (Guatemala: UNOPS, 1999).

20. They were actually legalised by Executive Decree 222 in 1983.

21. Simone Remijnse, Memories of Violence: Civil Patrols and the Legacy of Conflict in Joyabaj, Guatemala (Amsterdam: Thela Latin American Series, 2002), 143.

22. Schirmer, The Guatemalan Military Project; and Margaret Popkin, Las Patrullas Civiles Y Su Legado: Superar La Militarización Y Polarización del Campo Guatemalteco (Washington, DC: Centro de Derechos Humanos de la Organización Conmemorativa 'Robert F. Kennedy', 1996). 
23. Judith Zur, Violent Memories. Mayan War Widows en Guatemala (Boulder, CO: Westview Press, 1998); Remijnse, Memories of Violence; Matilde Gonzalez, Se cambió el tiempo. Conflicto y poder en territorio K'iche' (Guatemala: AVANCSO, 2002).

24. This paper still uses the abbreviation 'PAC' as this is the commonly used phrase in Guatemala.

25. Susanne Jonas, Of Centaurs and Doves: Guatemala's Peace Process (Boulder, CO: Westview Press, 2000).

26. For more detailed discussions see Ibid.

27. J.A. Solomon, Institutional Violence: Civil Patrols in Guatemala (Washington, DC: Robert F. Kennedy Memorial Center for Human Rights, 1994).

28. Further reading: Willem Stanley and David Holidy, 'Broad Participation, Diffuse Responsibility: Peace Implementation in Guatemala', in Ending Civil Wars: The Implementation of Peace Agreements, ed., Stephan John Stedman (Boulder, CO: Lynne Rienner Publisher, 2002); Wenche Hauge and Beate Thoresen, El destino de los ex combatientes en Guatemala: ¿Obstaculizadores o Agentes de Cambio? (Guatemala: Magna Terra, 2007).

29. Hauge and Thoresen, El destino de los ex combatientes en Guatemala.

30. Popkin, Las Patrullas Civiles Y Su Legado.

31. Hauge and Thoresen, El destino de los ex combatientes en Guatemala.

32. This was the result of the Global Agreement on Human Rights (Mexico, 24 March 1994), which stated that the participation of the CVDCs should be voluntary.

33. MINUGUA, La situación en Centroamérica: Procedimientos para establecer la paz firme y duradera, y progresos para la configuración de una región de paz, libertad, democracia y desarrollo (UN Documento A/49/856, 1995); MINUGUA, La situación en Centroamérica: Procedimientos para establecer la paz firme y duradera, y progresos para la configuración de una región de paz, libertad, democracia y desarrollo (UN Documento A/50/878, 1996).

34. The commissioners were another cornerstone of the militarisation of the rural areas. Initially they served as civilian intermediaries between the local population and the army, but during the war they were responsible for intelligence, surveillance and recruitment and were often chiefs of PAC. See CEH, Guatemala: Memoria del Silencio, vol. 2, 158-80.

35. Ricardo Saenz de Tejada, ¿Víctimas o vencedores? Una aproximación al movimiento de los exPAC (Guatemala: FLACSO, 2004).

36. Schirmer, The Guatemalan Military Project; Zur, Violent Memories; González, Se cambió el tiempo.

37. In 1995 there were 2643 groups of PAC counted see CEH, Guatemala: Memoria del Silencio.

38. González, Se cambió el tiempo; and Remijnse, Memories of Violence.

39. Pablo De Greiff, Contributing to Peace and Justice. Establishing Links between DDR and Reparations (Bonn: Working Group on Development and Peace, 2007).

40. Helen Mack, 'La reconciliación en Guatemala: un proceso ausente', in Verdad, justicia y reparación. Desafios para la democracia y la convivencia social, ed. Gilda Pacheco Oreamuno and Lorena Acevedo Narea (IIDH/IDEA International, 2005), 196.

41. Remijnse, Memories of Violence.

42. Solomon, Institutional Violence: Civil Patrols in Guatemala; Popkin, Las Patrullas Civiles Y Su Legado; and Schirmer, The Guatemalan Military Project.

43. REMHI, Guatemala: Nunca Más.

44. Former Head of the Secretary of Strategic Analysis (2000-2002) during the Portillo government, Minister of Foreign Affairs (2002-2004) and coordinator of the REMHI-project of the Catholic Church (1995-1998), e-mail interview, 15 September 2009.

45. Massacre of Santiago Atitlán (1993), Massacre of Xaman (May 2004), Case Rio Negro (May 2008).

46. Elizabeth Jelin, State Repression and the Labors of Memory (Minneapolis: University of Minnesota Press, 2003), 53-54.

47. Tristan Anne Borer, 'A Taxonomy of Victims and Perpetrators: Human Rights and Reconciliation in South Africa', Human Rights Quarterly 25 (2003): 1088.

48. Ibid., 1091.

49. Trudy Govier and Willem Verwoerd, "How Not To Polarize "Victims" and "Perpetrators", Peace Review 16, no. 3 (2004): 371.

50. A phrase I borrow from González, Se cambió el tiempo. 
51. This term refers mainly to people who identify themselves as non-indigenous, Spanish speaking and US/Europe oriented. Although $60 \%$ of the population is indigenous, the ladino culture is the dominant one.

52. Hereafter called: PAC programme.

53. Sáenz de Tejada, ¿Víctimas o vencedores?; and Hauge and Thoresen, El destino de los ex combatientes en Guatemala.

54. The FRG is the party of ex-general Efraín Ríos Montt. Under his regime (1982-1983) most killings, massacres and disappearances took place and he is seen as the architect of the genocide.

55. Sáenz de Tejada, ¿Víctimas o vencedores.

56. Edgar Gutierrez, email interview, 15 September 2009.

57. Amnesty International (AI), Guatemala. The Civil Defence Patrols Re-Emerge (London: Amnesty International, 2002); Remijnse, Memories of Violence.

58. For a more detailed discussion of the compensation debate, see USAID/CIEN, Informe sobre el aporte de capital a exPAC (Guatemala: USAID/CIEN, 2003).

59. AI, Guatemala. The Civil Defence Patrols Re-Emerge.

60. Sonia Pere, Prensa Libre, 13 July 2002.

61. Acuerdo Gubernativo 406-2005.

62. Interview with deputy Efrain Oliva Morales, sub-secretary of the Executing Coordination Secretary of the Presidency and responsible for the negotiation commission with PAC during the Berger government, 6 May 2009.

63. MINUGUA, Informe de Verificación. El estado de cumplimiento de las recomendaciones de la Comisión para el Esclarecimiento Histórico (Guatemala: MINUGUA, 2004); Gustavo Porras Castejon, 'El Programa Nacional de Resarcimiento: Cómo Se Quiso, Cómo Es y Cómo Debe Ser', In Primer Informe Temático 2006-2007 del Programa Nacional de Resarcimiento, La vida no tiene precio. Acciones y Omisiones de Resarcimiento en Guatemala (Guatemala: Magna Terra, 2007), 27-36.

64. General Agreement on Human Rights, VIII, Mexico D.F., 29 March 1994.

65. Recommendations III $-12 \& 13$.

66. Recommendations, III -11 .

67. Acuerdo Gubernativo 258-2003.

68. Acuerdo Gubernativo 619-2005.

69. Manual de Cualificación de Beneficiarios del Programa Nacional de Resarcimiento, PNR, 2004.

70. Programa Nacional de Resarcimiento, Informe de la evaluación conjunta del Programa Nacional de Resarcimiento y de los Programas de Apoyo al PNR de GTZ y PNUD (Guatemala: PNR, 2007); Programa Nacional de Resarcimiento, Informe de Labores 2008 (Guatemala: PNR, 2008); Programa Nacional de Resarcimiento, Informe de Labores 2009 (Guatemala: PNR, 2009).

71. Ibid.

72. CEH, Guatemala: Memoria del Silencio.

73. Alfonso Huet, Nos Salvó la Sagrada Selva. La Memoria de Veinte Comunidades Q'eqchi'es que sobrevivieron al Genocidio (Guatemala: Magna Terra, 2008).

74. Carlos Flores, Bajo La Cruz, Cobán (Guatemala: Centro Ak'kutan, 2001).

75. CEH, Guatemala: Memoria del Silencio.

76. Ibid., vol. 2, 230 and 234.

77. Personal communication with ex-collaborator of the CEH-office in Peten, April 2008, Guatemala ciudad.

78. AVANCSO, ¿Dónde está el futuro? Procesos de reintegración en comunidades de retorno (Guatemala: AVANCSO, 1992).

79. For more see: Centro de Estudios Integrados de Desarrollo Comunal, Guatemala. Polos de Desarrollo. El caso de la Desestructuración de las Comunidades Indígenas (México: Editorial Praxis, 1998).

80. AVANSCO, ¿Dónde está el futuro?; and Huet, Nos Salvó la Sagrada Selva.

81. Human Rights Watch/Americas, Guatemala. Return to Violence. Refugees, Civil Patrollers, and Impunity 8, no. 1 (B) (1996).

82. Between 2000 and 2006 there were 464 land conflicts with a concentration in municipalities of Cobán and San Pedro Carcha. Secretaría de Asuntos Agrarios Presidencia de la República 
Guatemala, Las ocupaciones de tierra en Guatemala: caracterización y líneas de atención. Informe Final (Guatemala: 2007).

83. Huet, Nos Salvó la Sagrada Selva.

84. CEH, Guatemala: Memoria del Silencio.

85. A phrase I borrow from Pouligny, Chesterman and Schnabel, 'Introduction: Picking up the Pieces'.

86. Roberta Culbertson and Béatrice Pouligny, 'Re-imagining Peace after Mass Crime: A Dialogical Exchange between Insider and Outsider Knowledge', in After Mass Crime. Rebuilding States and Communities, ed. Béatrice Pouligny, Simon Chesterman and Albrecht Schnabel (Tokyo: United Nations University Press, 2007), 271-88.

87. Tzuultaq'a ('Hill-Valley') or mountain spirits is a central concept determining the identity and being of the Q'eqchi'. It is omnipresent, guiding and overseeing of all actions of daily life. The idea of a personal, transcendent God is not inherent to their cosmovision; however they do not ignore the Christian God, as the majority of Q'eqchi' are Catholic. Esteban Haeserijn, 'Filosoía popular de lo K'ekchi' de hoy', Guatemala Indigena 10 (1975): 44-54; Agustín Estrada Monroy, Vida esotérica Maya-Kekchí (Guatemala City: Ministerio de Cultura y Deportes, 1990); Richard Wilson, Maya Resurgence in Guatemala. Q'eqchi' Experiences (Norman: University of Oklahoma Press, 1995).

88. Flores, Bajo La Cruz, 43.

89. As a reaction, the guerrillas attacked the village on 10 May 1982 ending in the massacre of 22 people, including two children.

90. Personal interview, May 2008.

91. The function of the ex-PAC is unpaid, whereas the mayor receives a salary from the Cobán municipality.

92. For an in-depth analysis on local Maya Q'eqchi' practices and attitudes on justice and reconciliation: Lieselotte Viaene, 'The Internal Logic of the Cosmos as 'Justice' and 'Reconciliation'. Micro-perceptions from Post-Conflict Guatemala', Critique of Anthropology 30, No. 3 (2010): 287-312.

93. Personal interview with dirigente ex-Pac in Salacium, May 2008.

94. For a fuller discussion of Mayan Q'eqchi' perceptions on the PNR see Lieselotte Viaene, 'Life is Priceless: Maya Q'eqhi' Voices on the Guatemalan National Reparations Program, International Journal of Transitional Justice 4, no. 1 (2010), 4-25.

95. PNUD, Informe Nacional de Desarrollo Humano. Diversidad etnico-cultural: la ciudadanía en un estado plural (Guatemala: PNUD, 2005), 332.

96. Interview, Coordinator Regional Office PNR, Cobán, 15 February 2010.

97. Interview, Roqha' Pasacuc, February 2010.

98. Interview, President National Victims Movement Q'anil Tinamit, 6 May 2009.

99. Interview, Public Functionary of the PNR, 18 March 2009.

100. For a fuller discussion: Lisa Laplante, 'The Law of Remedies and the Clean Hands Doctrine: Exclusionary Reparation Policies in Peru's Political Transition', American University International Law Review 23 (2007): 51-90.

101. Ibid., at 81 .

102. Interview with deputy Efrain Oliva Morales, sub-secretary of the Executing Coordination Secretary of the Presidency and responsible for the negotiation commission with PAC during the Berger government, 6 May 2009.

103. See the public statements of several human rights organisations and victim organisations, on the National Day of the Dignification of the Victims of the Conflict, 25 February 2009.

104. Mahmood Mamdani, When Victims Become Killers: Colonialism, Nativism, and the Genocide in Rwanda (Princeton, NJ: Princeton University Press, 2001), 273.

\section{Notes on contributor}

Lieselotte Viaene is a $\mathrm{PhD}$ researcher at the Human Rights Centre, Ghent University, Belgium. She has a background in criminology (BA, MA), with a master's degree in comparative cultural studies. Her research focuses on the intersection between human rights, legal anthropology and traditional justice with a case study of Guatemala. 